\title{
A STUDY OF INDONESIA ORIGINAL BRANDS FINANCIAL PERFORMANCE
}

\author{
Josua Tarigan*)1, Deborah Christine Widjaja*), Helene Lydia Egaputri*), and \\ Jean-Marc Dautrey ${ }^{* *}$ \\ *) Petra Christian University \\ Jl. Siwalankerto 121-131, Surabaya, Indonesia. \\ **) Stamford International University, Bangkok, Thailand \\ 16, Motorway Road - Km2, Prawet, Bangkok 10250 Thailand
}

\begin{abstract}
This research aimed at analyzing the influence of Indonesia Original Brand Index (IOB) on financial performance, which is measured by profitability and market value. The data of this research was from companies in various sectors listed in the Indonesia Stock Exchange (IDX) and whose brand appeared on the published index of Indonesia Original Brands of SWA magazine. The final number of samples is 68 firmyears. This research found that customers' satisfaction can enhance customer loyalty while also significantly improving customer advocacy. However, the performance of the Indonesia Original Brand Index still not significantly impacted financial performance. This issue happened due to the excessive resources of Indonesian companies, which spent on turning customers' loyalty and be advocates for the brand. This unfavorable profitability outcome can also be due to the unique characteristics of Indonesia's consumer behavior. According to $81 \%$ of IOB respondents, Indonesia's customers prefer to buy things at a low price and economically. With this behavior of seeking the lowest price, it indicates that customers in Indonesia may shift from one brand to other brands to get the best offer available, therefore not resulting in their constant purchase of one specific brand.
\end{abstract}

Keywords: indonesia original brands index, customer loyalty, customer advocacy, profitability, market value

\begin{abstract}
Abstrak: Tujuan dari penelitian ini adalah dalam rangka untuk menganalisa pengaruh Indonesia Original Brand Index (IOB) terhadap kinerja keuangan yang diukur dengan laba dan nilai pasar. Perusahaan yang terdaftar di Bursa Efek Indonesia (BEI) dan memiliki merk dagang terdaftar di Indonesia Original Brands Index yang dipublikasikan dalam majalah SWA merupakan data yang digunakan dalam penelitian ini. Jumlah akhir sampel adalah 68 perusahaan-tahun. Ditemukan bahwa kepuasan pelanggan dapat meningkatkan loyalitas dan anjuran pelanggan. Namun kinerja $I O B$ Index belum dapat secara langsung mempengaruhi kinerja keuangan. Hal ini terjadi karena banyak sumber daya yang dimiliki perusahaan digunakan untuk dapat membuat pelanggan puas dan menganjurkan merk dagang yang ada. Kondisi kinerja keuangan tersebut juga dipengaruhi oleh keunikan karateristik konsumen Indonesia. Sesuai dengan data $81 \%$ responden IOB Index, mengindikasikan bahwa pelanggan Indonesia lebih menyukai produk dengan harga terjangkau dan bernilai ekonomis. Dengan kondisi perilaku seperti ini, mengindikasikan bahwa masyarakat Indonesia dapat dengan mudah pindah dari satu merk dagang ke merk lainnya mengikuti tawaran terbaik yang ada. Hal ini akhirnya akan membuat loyalitas pembelian dalam satu merk tidak konsisten.
\end{abstract}

Kata kunci: indonesia original brands index, loyalitas pelanggan, anjuran pelanggan, laba, nilai pasar

${ }^{1}$ Corresponding author:

Email: josuat@petra.ac.id 


\section{INTRODUCTION}

Globalization has contributed to the shifting of business practices and changing business environments. Both existing companies and emerging companies are facing ,more significant business competition. Companies must compete with competitors to win customers, and customer satisfaction is one of the keys for companies to continue to exist in the era of globalization (Blocher et al. 2013).

Indonesia considered a big potential market with a population of 255 million. Citizens of Indonesia are always excited to try new products or services, thus, inducing the emerging of new brands. Based on the data of the Directorate General of Intellectual Property Rights (HKI), the number of brand applications has grown from 42,777 in the year 2009 to 44,596 in the year 2014 (Suryadi, 2015). With this growing number of brands available for the customer, a company needs to stay aware and pay more attention to win the market when facing tight competition. The establishment of the ASEAN Economic Community (AEC), in 2015, allows more foreign companies to enter Indonesia's market and make the competition even more competitive. Therefore, it is necessary to make the customers feel satisfied in the first place to create loyal customers who have the willingness to be advocates for the brand. Loyal customers would be willing to pay higher prices and have the desire to recommend the brand to others through brand advocacy (Shailesh and Reddy, 2016).

Several pieces of research have investigated the relationship about customer satisfaction, loyalty, advocacy, and financial performance. Contented customers are profitable for a company because there will be more possibility of repeat patronage by such customers who are loyal to the company (Rai \& Srivastava, 2012). Since organizations need a loyal customer base for profits and continuous growth (Ou et al. 2011). In this case, customer loyalty as the direct outcome of customer satisfaction drives the organization's profit and growth (Hasouneh and Allafi, 2012). Customer loyalty improves a company's profitability through the increase in revenue, winning new customers by cost reduction and word of mouth communication (Castañeda, 2011). According to Hua et al. (2018), profits can be increased from $25 \%$ to $85 \%$ if the potential migration is decreased by $5 \%$ depending upon the industry. When there is loyalty, customers will keep on buying the products or services and recommend their family and friends to buy the products or services as well instead of those of the competitors (Ganiyu et al. 2012). It means that loyal customers get converted into customer advocates, attracting prospective customers on behalf of the organizations (Shailesh and Reddy, 2016). Customer advocacy is the inclination of the consumer to support the product and service seller by providing positive recommendations to other consumers (Badrinarayanan and Sierra, 2018). Walker stated that the likelihood of loyal customers to purchase at higher prices and to endorse the brand to others through brand advocacy would be higher (Shailesh and Reddy, 2016). However, there are some inconsistencies in prior to researches. As some studies suggested that customer satisfaction and customer loyalty have a positive relationship with profitability performance, while other researches argue that customer satisfaction and customer loyalty do not have a significant relationship.

Moreover, there are only a few studies that evaluate the relationship of customer satisfaction, customer loyalty, customer advocacy, and profitability performance and market value in one analysis model, especially for companies in Indonesia. Additionally, since there was no previous study on the relationships of the four variables, customer satisfaction, loyalty, advocacy, and financial performance, on Indonesia Original Brand, this research is in the position to provide a pioneer reference for a study of its financial performance. Therefore, this study wants to fill the gap of customer satisfaction, loyalty and advocacy literature in an Indonesian context. Furthermore, there has been little study of using overall financial performance, which used in this research.

This research aimed to examine the influence of customer satisfaction on financial performance and customer advocacy with the role of customer loyalty as the intervening variable on companies of all sectors listed in the Indonesia Stock Exchange. The specific objectives of this research are to examine the link between satisfaction, loyalty, and advocacy and to find out the distinction of customer satisfaction impact on short term financial performance measured with profitability and on long term financial performance measured with market value. Furthermore, this research explores the financial performance from short-term financial results, which is profitability (Tarigan et al. 2019) and also long-term financial performance measured by market value. This issue happens, since 
NPM (net profit margin ) as one of the most widely known profitability (Keisidou et al. 2013) perceived to represent a short-term measurement but not a futureoriented measure. Besides, it is susceptible to tax laws and accounting conventions as it could be manipulated more easily than capital market data (O'Sullivan and McCallig, 2012). Thus, this research measures firmvalue with Tobin's q, which considered as a longterm performance and a future-oriented measure. The research done towards the company listed in Indonesia Stock Exchange during the year 2011-2015, and companies whose brands included in Indonesia Original Brands (IOB) in SWA magazine for the year 2011-2015.

\section{METHODS}

This study conducted in Surabaya, in the period between February-July 2016. The data of this research was from companies in various sectors listed in Indonesia Stock Exchange (IDX) and whose brand appeared on the published index of Indonesia Original Brands (IOB) of SWA magazine during 2011-2015. The variables used to decide on the Top 250 Indonesia Original Brands Index are satisfaction, loyalty, and advocacy. SWA Magazine Indonesia conducted this survey. SWA Magazine in Indonesia's business magazine, which consistently publishes national marketing indexes, such as the Indonesia Original Brands Index, Indonesia Best Brand Award Index, and Indonesia Customer Satisfaction Index. First published thirty-two years ago, now SWA Magazine has been recognized as credible media in Indonesia and is widely used as a reference by many companies and academics. Each variable has a different sub-variables. The sub-variables of satisfaction are a core function of the product, as well as overall quality and brand value. Loyalty consists of attitude toward brand and repurchasing. Advocacy consists of talking, recommending and pleading. Respondents of IOB survey chosen randomly using multistage random sampling, with the combination of booster sampling methods from 6 major cities in Indonesia, which are Jabodetabek, Bandung, Semarang, Surabaya, Makassar and Medan. For each brand, the survey targeted a minimum number of 50 respondents to make a stable assessment for the brand. Respondents asked to state the local brands that they had ever used and then fill out the questionnaires given. This research utilizes the satisfaction index, loyalty index and advocacy index from Indonesia Original Brands publication for the years 2011-2015.

From the purposive sampling process, there are 52 brands included in IOB, all from the years 2011-2015. The 37 company brands are not listed in the Indonesia Stock Exchange, thus leaving the number of the brand sample as 15. As two brands are coming from the same company, the number of group samples left is 14 . One company only started to be listed in IDX from the year 2013. Therefore, the final number of samples is 68 firm-years. Table 1 shows the list of companies.

Table 1. List of companies

\begin{tabular}{ll}
\hline No & Company \\
\hline 1 & PT Astra Otoparts Tbk \\
2 & PT Gajah Tunggal Tbk \\
3 & PT HM Sampoerna Tbk \\
4 & PT Indofood CBP Sukses Makmur Tbk \\
5 & PT Indofood Sukses Makmur Tbk \\
6 & PT Industri Jamu dan Farmasi Sido Muncul Tbk \\
7 & PT Kalbe Farma Tbk \\
8 & PT Ricky Putra Globalindo Tbk \\
9 & PT Semen Indonesia Tbk \\
10 & PT Sinar Mas Agro Resources and Technology Tbk \\
11 & PT Tempo Scan Pacific Tbk \\
12 & PT Ultrajaya Milk Industry Tbk \\
13 & PT Unilever Indonesia Tbk \\
14 & PT XL Axiata Tbk \\
\hline
\end{tabular}

The data applied in this research are secondary data from several sources. All the data of customer satisfaction, loyalty, and advocacy retrieved from IOB Index (SWA magazine). While the data of companies' financial performance, such as net profit after tax and net sales, as well as market capitalization, total debt, and total assets, is taken from company financial reports in Indonesia Stock Exchange (IDX) website and Bloomberg.

This research uses Partial Least Square (PLS), to evaluate the effect of customer satisfaction on financial performance and customer advocacy, with customer loyalty as the intervening variable. PLS is suitable for this research because this research comprised of several latent variables that could not be observed or measured directly. Therefore they need to be assessed indirectly through the use of manifest variables or indicators. 
Customer satisfaction is the customer's judgment; whether a product or a service complies or not with their expectation (O'Sullivan and McCallig, 2012). It concerns the favorableness of the individual customer's assessment of the final results and encounters related to the product. Satisfied customers generate and maintain profound psychological bonds with favored brands. At the same time, they can recognize favored brands very swiftly, which stimulates market penetration and expansion strategies (Hasouneh and Allafi, 2012). Customer satisfaction can measured by using a customer satisfaction index. A key advantage of using a satisfaction index as a satisfaction measure is the practical reliability across all the companies. The measurement utilizes a similar survey instrument, interviewing method and statistical techniques to construct the satisfaction index. Thus, it makes sure that a variant in observed satisfaction scores cannot attribute to practical inconsistencies (Koudah and Farley, 2016).

Furthermore, customer loyalty is the association of customer attitude, repeat purchasing, and financial performance (Biscaia et al. 2012). According to Kursunluoglu (2014), loyalty is formed based on customers' experiences, consisting of emotional involvements, physical interactions and value chain moments. Attitudinal and behavioral loyalty are two popular conceptualizations of customer loyalty (Biscaia et al. 2012). Attitudinal loyalty is the preferences, purchase intention, supplier prioritization and customer's inclination to endorse. While behavioral loyalty is the frequency of purchase, the sequence of purchase or the likelihood of repurchase buying behavior (TaghiPourian and Bakhsh, 2015). The relationships between customer satisfaction and customer loyalty come in many types, for example, satisfaction as the heart of loyalty, satisfaction as the primary element of loyalty, satisfaction, and loyalty as the essential constituents of ultimate loyalty, as well as satisfaction as the initiation of loyalty. Minh and Huu (2016) stated that customer satisfaction could lead to loyalty because generally, people are inclined to be risk-averse and sensible. They would rather avoid risk by staying with the same service givers with whom they had already a pleasant experience. Hence, the following hypothesis would be worth testing:

H1: Customer satisfaction has a positive impact on customer loyalty.
Financial performance is the extent to which the organization has done financial goals. The financial performance measure is important because the primary objectives of companies are the maximization of shareholder wealth through profit generation, survival, and growth. One of the most measured financial performances is the profitability of the company (Keisidou et al. 2013). Profitability ratios show that a company can get an agreeable profit and return on investment (Tarigan et al. 2019). In this research, financial performance will measured by using a profitability ratio. The ratio used is the net profit margin (NPM). Net profit margin (NPM) assesses profitability after considering all revenues and expenses, including taxes, interest, and non-operating items. NPM is the bottom line margin regularly cited for companies. It represents the company's ability to translate sales into profits at different stages of measurement and the company's ability to control cost. If the company cannot turn sales into profit, it indicates that the company is losing money and that owners may need to shut down the company. NPM is the indicator of the effectiveness of the management in converting revenues into earnings presented for shareholders. NPM could calculated by dividing net profit after tax with net sales.

The service-profit chain put forward the positive association between customer satisfaction and financial performance. In this case, higher customer satisfaction will result in higher financial performance (Tarigan and Hatane, 2019). However, there have been some inconsistencies with the findings related to the association between customer satisfaction and profitability. For instance, a business might spend too large sum of money to attempt to increase its customer satisfaction (Tarigan and Hatane, 2019), which will lead to diminishing profitability. Customers who retained considered as a revenue-producing asset for the company (Hasouneh and Allafi, 2012). However, Izogo and Ogba (2015) also implies that not all customers are as prospective concerning revenue generation, because the value of customers attained may diminish with the higher maintenance costs and lower revenue, leading to decreasing returns from getting new customers. Thus, the company should function at a stable state and concentrate on attaining and retaining the right loyal customers, rather than thoughtlessly growing its customer base. An organization that precisely aims at customers who most probably bring profitable referrals will gain a better return than the competitors which do not (Tarigan and Hatane, 2019). Hasouneh and Allafi 
(2012) stated that loyal, satisfied customers are likely to spread the affirmative word of mouth which decreases the cost of gaining new customers and improves the company's whole reputation, while discontented customers will give the reverse outcome. Hence, the following hypotheses would, therefore, tested:

H2: Customer satisfaction has a positive impact on profitability performance.

H4a: Customer loyalty has a positive impact on profitability performance.

H5a: Customer advocacy has a positive impact on profitability performance.

Customer advocacy is the willingness of the consumer to support the product and service seller by providing positive recommendations to other consumers (Schepers and Nijssen, 2018). Customer advocacy intended to create profound customer relationships by gaining new degrees of commitment and trust and by building mutual transparency, dialogue, and partnership with customers (Schepers and Nijssen, 2018). Consumers will take action as promoters for a brand or a product or service, as they give positive comments and recommend it to others (Susanta et al. 2013). Customer advocacy ,at times, designated as positive word-of-mouth (Schepers and Nijssen, 2018). Advocacy is essential in marketing since consumers depend on counsels from their groups and follow those counsels accordingly (Keylock and Faulds, 2012). Potential consumers think information and facts from connections as less opinionated and more reliable when compared to the information from a company (Shailesh and Reddy, 2016). Hua et al. (2018) claimed that customers' readiness to recommend the company to their friends and relatives at the cost of their reputation signifies strong customer relationships. Customer loyalty and customer advocacy deemed to have a very prevailing association with each other (Shailesh and Reddy, 2016). According to Grisaffe and Nguyen (2011), consumers who are emotionally devoted to a brand will have the eagerness to draw others to the brand through brand advocacy, as they are inclined to promote the brand to their peer groups. Accordingly, the next hypothesis put forward:

H4b: Customer loyalty has a positive impact on customer advocacy

Ratio measures such as NPM is beneficial as it has better comparability through the company in the same industry. However, NPM as a short-term performance measurement represents accounting profit, which accounts for previous profitability and is not a futureoriented measure. The implementation of different accounting principles will affect accounting profit and further affect financial ratios calculated, as the company may cook the books to manipulate their financial reports and create favorable profitability results. Tobin's q is a future-oriented, capital market-based measure used to determine the value of a company. It is the ratio of a company's market value to the substitute cost of its assets (O'Sullivan and McCallig, 2012). A company with a higher market value than the substitute cost of its assets seen as utilizing the resources more successfully as well as producing intensified shareholder value (Koudah and Farley, 2016). A company without incremental value has Tobin's q equal to 1 . In this case, the disparity between a company's Tobin's q and 1 signifies the extent of expected future irregular returns (O'Sullivan and McCallig, 2012). The adapted form of Tobin's q, elaborated by O'Sullivan and McCallig (2012), was applied in this study in a ,more straightforward balance. For that reason, the following formula applied:

\section{Tobin's q $=(\mathrm{MVE}+\mathrm{DEBT}) / \mathrm{TA}$}

In this case, MVE represents the company's share price times common stock shares outstanding number. DEBT is the company's short-term liabilities value plus the company's long-term debt. Hence TA is the company's total assets book value. The positive association between market value indicators and satisfaction generated as more high customer satisfaction inclines to raise the advantages obtained from customer loyalty. When customers are loyal, they tend to have fewer complaints and more cross-selling, thus leading to the company's revenue growth. On the other hand, it precedes to more extended enhanced financial performance, and in the end, it will positively influence on company valuation indicators and stock prices (Williams and Naumann, 2011).

With the statements above, the following hypotheses would be worth testing:

H3: Customer satisfaction has a positive impact on market value.

$\mathrm{H} 4 \mathrm{c}$ : Customer loyalty has a positive impact on market value.

H5b: Customer advocacy has a positive impact on market value. 
From the descriptions, this study was to examine the role of customer loyalty and customer advocacy in strengthening customer satisfaction to financial performance, which is measured by profitability and market value. Therefore, this research analyzes the association between dependent variables and independent variables, with the following definitions and models in Figure 1.

a. The independent variable is customer satisfaction

b. The intervening variable is customer loyalty.

c. Profitability performance, market value and customer advocacy as dependent variables.

\section{RESULTS}

This research uses Partial Least Square (PLS) with software smartPLS to evaluate the impact of customer satisfaction on financial performance and customer advocacy with customer loyalty as the intervening variable. The path diagram below shows the relationships between the variables used in this research. The evaluation of this PLS model will done by evaluating the measurement model (outer model) and the structural model (inner model) (Figure 2).

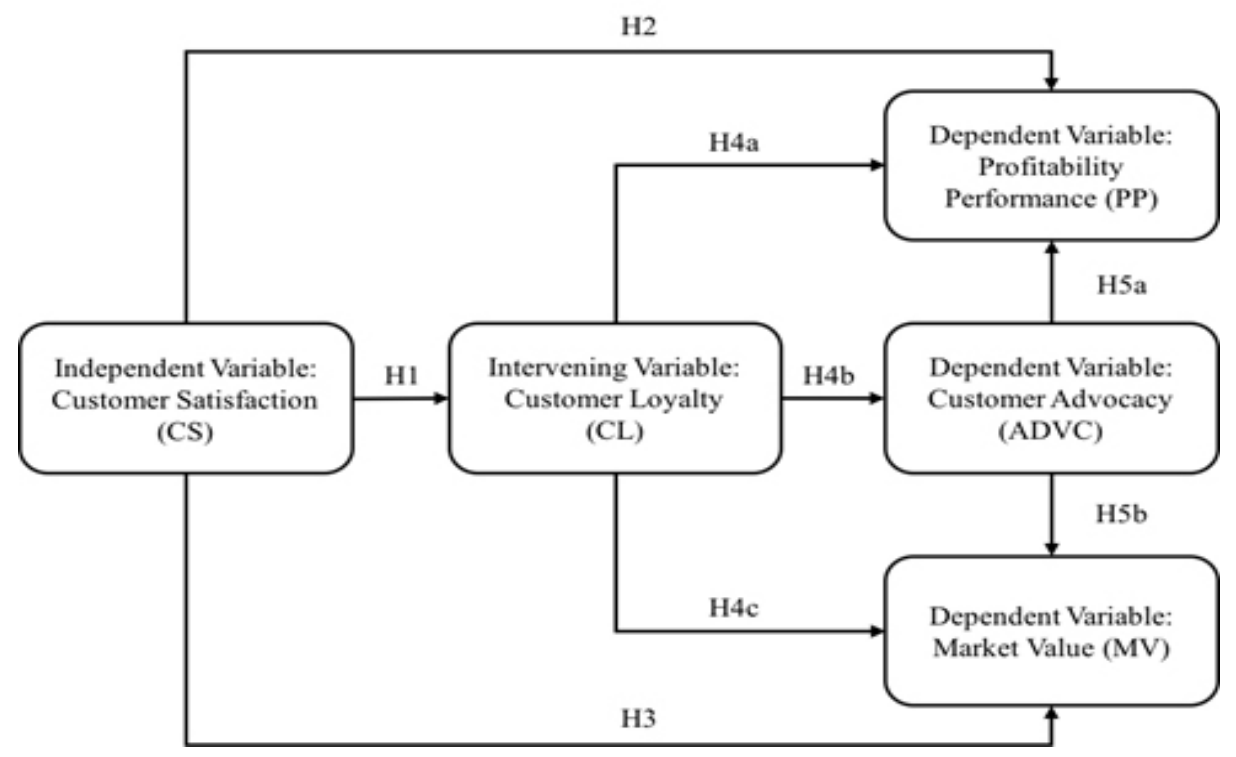

Figure 1. Research model

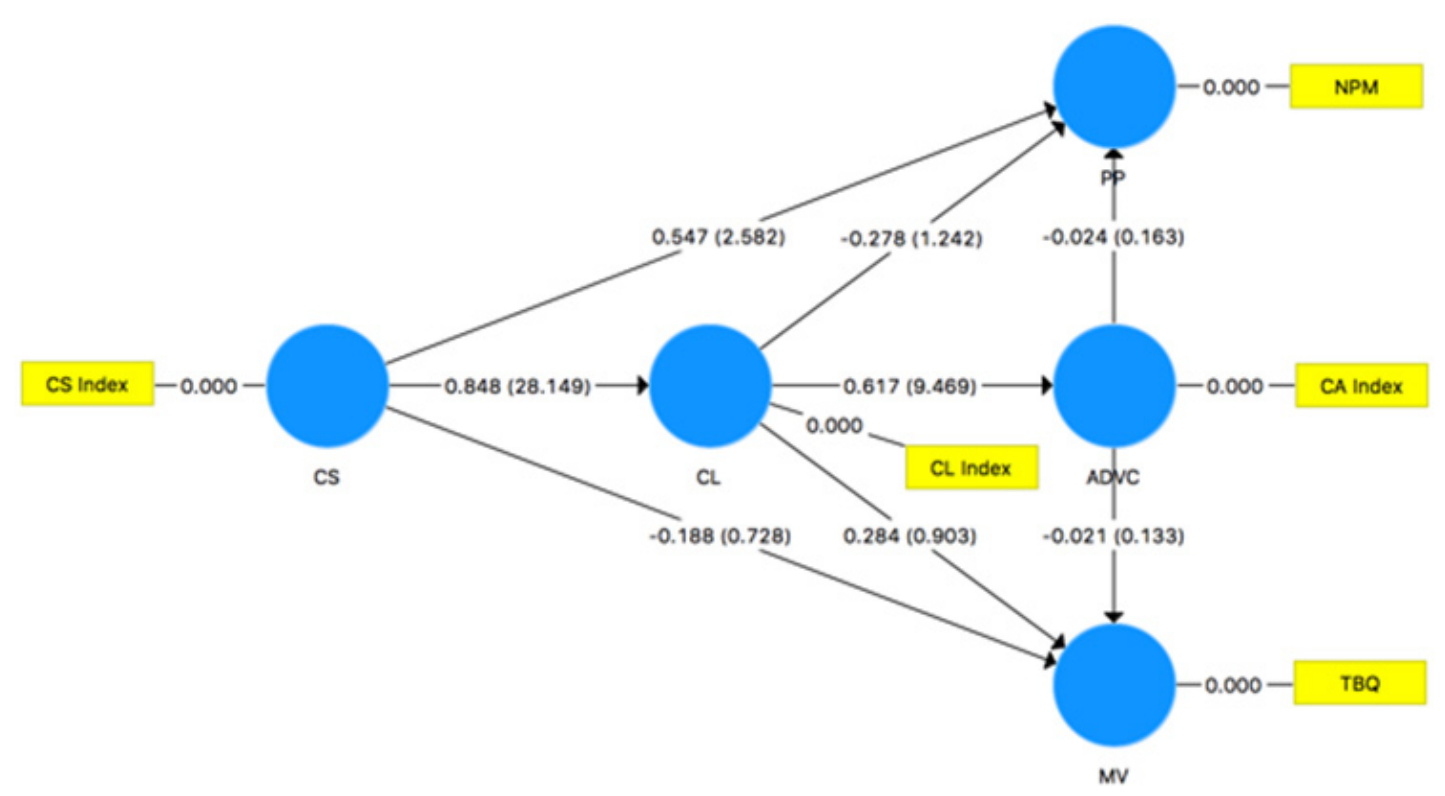

Figure 2. PLS Path Diagram 
The outer loading value of each indicator toward the latent variable is more than 0,7 . It indicates that the indicators and the latent variables used in this research have a high correlation. Therefore, already fulfill the convergent validity, and no indicator elimination is needed based on this test. In conducting the discriminant validity test, this test will take a look at the loading and the cross-loading value for each indicator. The discriminant validity test requires that the loading value for each indicator must be ,more significant than the cross-loading value of other latent variables. Table 2 figured out that the indicators used in this research to measure the corresponding variables already fulfill the discriminant validity because every indicator has the most significant cross-loadings value for their measured latent variable and not for the other latent variables. Therefore, this output indicates that the indicators used in this research already fulfill the discriminant validity thus could be used for further research.

Square root of AVE of latent variable could also used to determine discriminant validity by matching the square root of AVE for each variable with the relationship between that variable with the other variables within the model. If the square root of the AVE for each construct is ,more extensive than other correlation values among the latent variables, and the value of square root of $A V E>0.5$, it can be decided that the variable has good discriminant validity. From Table 3, the value of the square root of AVE for each variable is ,more significant than the value of the relationship of other correlation values among the latent variables. Therefore, it can determined that the variable has good discriminant validity.

An internal consistency reliability test is needed to show accuracy, consistency, and the appropriateness of indicators to measure latent variables. Based on Table 4, all variables in the model have a composite reliability value of more than 0,7 . This output indicates that the indicators used in this research already fulfill the reliability test and have the accuracy, consistency and appropriateness of indicators to measure latent variables.

Q-square

$=1-[(1-0.719) \times(1-0.381) \times(1-0.114) \times(1-0.023)]$

$=0.849$

From the calculation above, the Q-square value is 0,849 . This value implies that the variance of research data that can be justified by the research model is $84,9 \%$. The remaining $15.1 \%$ justified by other factors not included in research models, such as brand loyalty, brand equity, employee satisfaction, and good corporate governance. Additionally, with the result shown above, it can be concluded that this research has good goodness-of-fit.

From Table 5, we can see that 3 out of 8 hypotheses proposed are acceptable. The first hypothesis is accepted, since the path coefficient of customer satisfaction to customer loyalty is 0.848 , and the t-statistic is $28.149>$ 1.96. This finding indicates the positive and significant impact of customer satisfaction on customer loyalty. Customer satisfaction and customer loyalty relationship also have a high R-square value of 0.719 , which means that customer satisfaction can better predict changes in customer loyalty. The tendency that people are rational and risk-averse so that they tend to lessen risk may explain the relationship between customer satisfaction and customer loyalty. Thus, customers prefer to stay with the service or product providers that they have already had a good experience with (Minh and Huu, 2016). A customer will appreciate his or her transactions with a provider who can repeatedly satisfy him (Keisidou et al. 2013).

Table 2. Cross loadings value

\begin{tabular}{lccccc}
\hline & CS & CL & ADVC & PP & MV \\
\hline CSI & 1.000 & 0.848 & 0.523 & 0.299 & 0.042 \\
CLI & 0.848 & 1.000 & 0.617 & 0.171 & 0.112 \\
CAI & 0.523 & 0.617 & 1.000 & 0.091 & 0.056 \\
NPM & 0.299 & 0.171 & 0.091 & 1.000 & 0.509 \\
TBQ & 0.042 & 0.112 & 0.056 & 0.509 & 1.000 \\
\hline
\end{tabular}

Table 3. Square Root of AVE and relationship between variables

\begin{tabular}{lcccccc}
\hline & AVE & CS & CL & ADVC & PP & MV \\
\hline CS & 1.000 & 1.000 & & & & \\
CL & 1.000 & 0.848 & 1.000 & & & \\
ADVC & 1.000 & 0.523 & 0.617 & 1.000 & & \\
PP & 1.000 & 0.299 & 0.171 & 0.091 & 1.000 & \\
MV & 1.000 & 0.042 & 0.112 & 0.056 & 0.509 & 1.000 \\
\hline
\end{tabular}

Table 4. Composite reliability value

\begin{tabular}{lc}
\hline & Composite Reliability \\
\hline $\mathrm{CS}$ & 1.000 \\
$\mathrm{CL}$ & 1.000 \\
$\mathrm{ADVC}$ & 1.000 \\
$\mathrm{PP}$ & 1.000 \\
$\mathrm{MV}$ & 1.000 \\
\hline
\end{tabular}


Table 5. Path coefficient value and T-statistics

\begin{tabular}{lccc}
\hline Correlation & Path Coefficient & T-statistics & Remarks \\
\hline $\mathrm{CS} \rightarrow \mathrm{CL}(\mathrm{H} 1)$ & 0.848 & 28.149 & Accepted \\
$\mathrm{CS} \rightarrow \mathrm{PP}(\mathrm{H} 2)$ & 0.547 & 2.582 & Accepted \\
$\mathrm{CS} \rightarrow \mathrm{MV}(\mathrm{H} 3)$ & -0.188 & 0.728 & Rejected \\
$\mathrm{CL} \rightarrow$ PP $(\mathrm{H} 4 \mathrm{a})$ & -0.278 & 1.242 & Rejected \\
$\mathrm{CL} \rightarrow \mathrm{ADVC}(\mathrm{H} 4 \mathrm{~b})$ & 0.617 & 9.469 & Accepted \\
$\mathrm{CL} \rightarrow \mathrm{MV}(\mathrm{H} 4 \mathrm{c})$ & 0.284 & 0.903 & Rejected \\
$\mathrm{ADVC} \rightarrow$ PP $(\mathrm{H} 5 \mathrm{a})$ & -0.024 & 0.163 & Rejected \\
$\mathrm{ADVC} \rightarrow \mathrm{MV}(\mathrm{H} 5 \mathrm{~b})$ & -0.021 & 0.133 & Rejected \\
\hline
\end{tabular}

The second hypothesis is also accepted, because the path coefficient of customer satisfaction to profitability performance is 0.547 , and the t-statistic is $2.582>$ 1.96. This finding shows that customer satisfaction has a positive association with profitability performance. Customer satisfaction will bring some consequences, including quickening of cash flows, growth in the level of cash flows, and a decline in the risk associated with cash flows (Tarigan and Hatane, 2019).

Another hypothesis that is accepted is $\mathrm{H} 4 \mathrm{~b}$, since the path coefficient of customer loyalty to customer advocacy is 0.617 , and the t-statistic is $9.469>1.96$. This finding indicates that customer loyalty has a positive relationship with customer advocacy. An increase in customer loyalty will lead to a significant and positive increase in the customer advocacy of companies in various sectors evaluated in the study sample. The R-square value of customer advocacy is 0.381 , which means that the percentage of changes in customer advocacy that can be explained by customer satisfaction and customer loyalty is $38.1 \%$. Committed customers are more likely to have the willingness to function as voluntary marketing advocates and involve in positive word-of-mouth recommendations (Schepers and Nijssen, 2018). The willingness to make the recommendation is an indicator of loyalty because customers act as references, and they put their reputations on the line as they feel intense loyalty (Hasouneh and Allafi, 2012). It is vital to meet customer hopes and keep them by providing different experiences constantly, as the role of customer loyalty is crucial in enhancing customer advocacy (Shailesh and Reddy, 2016).

The hypotheses that rejected can found in $\mathrm{H} 3, \mathrm{H} 4 \mathrm{a}, \mathrm{H} 4 \mathrm{c}$, $\mathrm{H} 5 \mathrm{a}$, and H5b. Hypothesis 4a, which mentioned that customer loyalty has a positive impact on profitability performance, is rejected. Thet-statistics are 1.242<1.96.
This score indicates that customer loyalty does not have a relationship with profitability performance. Despite the significant impact of satisfaction on profitability, the R-square value of profitability performance is only 0.114 , because both customer loyalty and customer advocacy do not impact profitability significantly. Keiningham et al. (2014) suggested that single-brand loyalty has replaced with loyalty to multiple brands in a category in many sectors. Thus, customers partially give more of a share of their spending in the category to other competitors. According to the survey conducted by Boston Consulting Group (BCG) with 3,000 Indonesian customers, it revealed that Indonesian customers have low levels of brand loyalty (Rastogi et al. 2016). Regardless of their prior experience with the specific brand, more than one-third intend to try the different brands in their next transaction. Thus, the attempt to make a customer loyal may not improve a company's profitability significantly. This issue happened because the Indonesia Original Brand is more of a new player compared to International brands' products/services.

Furthermore, Ganiyu et al. (2012) suggested that usually, a discount given to make loyal customers stay, so lowering prices will harm profits. Magatef and Tomalieh (2015) and Hasouneh and Allafi (2012) assumed that companies might spend too many resources on building customer loyalty, which leads to decreasing profitability. Gandomi and Zolfaghari (2013) proved that, if the company manages to maintain satisfaction among customers, the company would have optimal profitability by not offering a loyalty reward. This unfavorable profitability outcome could also be due to the unique characteristics of Indonesia's consumer behavior. Kurabayashi et al. (2013) surveyed to understand customer behavior in five ASEAN countries, which are Malaysia, Thailand, Indonesia, Vietnam, and Myanmar. From the survey, it discovered that Indonesia's customers have the most prominent 
price sensitivity compared to the other four countries, with $81 \%$ of respondents preferring to buy things at the low price and economically. With this behavior to seek the lowest price, it indicates that customers in Indonesia may shift from one brand to other brands to get the best offer available. Therefore they might not regularly purchase from one specific company.

Hypothesis three (H3), which states that customer satisfaction has a positive impact on market value, is rejected. This rejection is due to the t-statistic $0.728<$ 1.96, which indicates that customer satisfaction does not have a significant impact on market value. When the relationship between customer loyalty to market value tested (H4c), it also shows an insignificant effect since the t-statistic is $0.903<1.96$. The impact of customer advocacy on market value (H5b) also shows an insignificant effect because the t-statistic is $0.133<$ 1.96. The low market value's R-square of 0.023 also justifies the low percentage of changes in market value, which can be explained by customer satisfaction, customer loyalty and customer advocacy. Magatef \& Tomalieh (2015) also found no evidence that customer satisfaction and market value react promptly in their studies. There is no short-run impact on customer satisfaction announcements on stock prices. Companies with highly contented customers usually create positive irregular returns, but information about changes in customer satisfaction does not have an instantaneous influence on stock prices.

Hypothesis 5a, which states that customer advocacy has a positive impact on profitability performance, is rejected. The t-statistic of customer advocacy to profitability performance is $0.163<1.96$. This score reveals that there is no association between customer advocacy and profitability performance. Schepers and Nijssen (2018) suggests that advocacy is a mutual interest between the company and its customers. A customer will develop long-term trust and tell others about the company. Therefore less money is spent on advertising and promotion. In return, the company needs to listen to customers' advice on the products and services they want, then design the new product or service that suits their interests, which will create more costs spent on communication methods and product design. This cost will lead to declining profits in the short run and often seen as a difficult ethical decision. Furthermore, Schmitt et al. (2011) declared that profit margins from referred customers are considerably higher only at the beginning, but diminish over time and vanish after two and a half years, as referred customers could find the quality they want and are willing to pay for. The company starts to target its marketing accordingly.

\section{Managerial Implications}

The result of the research illustrates that customer loyalty has a negative and insignificant impact on profitability performance and market value but a positive and significant impact on customer advocacy. Even though customer loyalty will not have a significant impact on the company's profitability performance, the company still needs to maintain the level of customer loyalty to take advantage of customer advocacy. Still, managers should be cautious of the cost-effectiveness of the customer loyalty program.

\section{CONCLUSIONS AND RECOMMENDATIONS}

\section{Conclusions}

The result of the research proves that customer satisfaction has a positive and significant impact on profitability performance. Therefore, the company could pay more attention to customer satisfaction to improve the company's profitability performance. The company could run customer relationship marketing, provide a better customer experience, offer more innovative products, and understand the determinants of customer satisfaction to consider the policies and processes that must undertaken to provide the best value for the customer. Nevertheless, managers should make the right decisions for their businesses to ensure the increase in customer satisfaction, along with the increase in cost to make it happen, will bring a greater increase for the company's profitability performance.

While it is true that customer is important, it is still necessary to be cautious about putting not too much emphasis and concentration on customer satisfaction. If managers put excessive concerns on customer relationships, it may indicate that the manager wants to protect his benefits by improving profitability for a favorable short term performance instead of maximizing the shareholder's wealth in the long-run. This practice would oppose the view of agency theory. Agency theory explains the relationship between a principal and the agent employed by the principal to carry out tasks on their behalf. According to agency theory, for the task undertaken, the agent should be accountable 
to the principal. When shareholders delegate control to managers, managers have a fiduciary responsibility to operate for the best interests of shareholders, which is wealth maximization. However, managers may have their own goals, such as high salary and bonus achievement. This separation of goals will lead to a conflict of interest between shareholders' goals and managers' goals or referred to as an agency problems. Therefore, the company needs to pay attention to all stakeholders, including both customers and shareholders. A robust policy might be useful to minimize the conflict of interest between shareholders and managers.

\section{Recommendations}

This research has attempted to figure out the distinction of customer satisfaction impact on short term financial performance (company's profitability) and long term financial performance (company's market value). To further explain the relationship of customer satisfaction with short term and long term performance, the author would like to suggest the evaluation of customer satisfaction influence to market value through the intervention of profitability performance for future research. Therefore, this research will serve as a basis for future studies in Indonesia Original Brand Financial Performance and enrich customer satisfaction, loyalty and advocacy literature.

\section{REFERENCES}

Badrinarayanan V, Sierra JJ. 2018. Triggering and tempering brand advocacy by frontline employees: vendor and customer-related influences. Journal of Business and Industrial Marketing 33(1):42-52. https://doi.org/10.1108/ JBIM-06-2016-0137.

Biscaia AR, Rosa MJ, Sa PM, Sarrico, CS. 2012. Assessing customer satisfaction and loyalty in the retail sector. International Journal of Quality \& Reliability Management 34(9):1508-1529. https://doi.org/10.1108/IJQRM-03-2015-0039.

Blocher E, Stouth D, Juras P, Cokins G. 2013. Cost Management: A strategic emphasis sixth edition. New York: McGraw-Hill Company.

Castañeda JA. 2011. Relationship between customer satisfaction and loyalty on the internet. Journal of Business and Psychology 26(3):371-383. https://doi.org/10.1007/s10869-010-9196-z.
Ganiyu RA, Uche II, Elizabeth AO. 2012. Is Customer Satisfaction an Indicator of Customer Loyalty? Australian Journal of Business and Management Research 2(7):14-20

Gandomi A, Zolfaghari S. 2013. Profitability of loyalty reward programs: An analytical investigation. Omega 41(4):797-807. https://doi.org/10.1016/j. omega.2012.10.003.

Grisaffea DB, Nguyen HP. 2011. Antecedents of emotional attachment to brands. Journal of Business Research 64(10):1052-1059. https:// doi.org/10.1016/j.jbusres.2010.11.002.

Hua N, Wei W, DeFranco AL, Wang, D. 2018. Do loyalty programs really matter for hotel operational and financial performance?. International Journal of Contemporary Hospitality Management 30(5):2195-2213. https://doi.org/10.1108/ IJCHM-12-2016-0643.

Hasouneh AI, Allafi KK. 2012. Factors Associated with Customer Satisfaction and Financial Performance: A Case Study with Dubai Islamic Banks in Jordan. Journal of Baghdad College for Economic Sciences 29:369-391.

Izogo, EE, Ogba, IE. 2015. Service quality, customer satisfaction and loyalty in automobile repair services sector. International Journal of Quality and Reliability Management 32(3):250-269. https://doi.org/10.1108/IJQRM-05-2013-0075.

Keiningham T, Gupta S, Aksoy L, Buoye A. 2014. The high price of customer satisfaction. MIT Sloan Management Review 55(3):1-20.

Keisidou E, Sarigiannidis L, Maditinos DI, Thalassinos EI. 2013. Customer satisfaction, loyalty and financial performance A holistic approach of the Greek banking sector. International Journal of Bank Marketing 31(4):259-288. https://doi. org/10.1108/IJBM-11-2012-0114.

Keylock MH, Faulds M. 2012. From customer loyalty to social advocacy. Journal of Direct, Data and Digital Marketing Practice 14(2):160-165. https://doi.org/10.1057/dddmp.2012.37.

Kurabayashi T, Niimi Y, Yatsunami S. 2013. Understanding ASEAN consumer markets through country-specific questionnaires. Nomura Research Institute Paper 192:1-13.

Kursunluoglu, E. 2014. Shopping centre customer service: creating customer satisfaction and loyalty. Marketing Intelligence \& Planning 32(4):528-548. https://doi.org/10.1108/MIP-112012-0134.

Koudah EY, Farley AY. 2016. Relationship between 
Customer Satisfaction and Customer Loyalty in the Retail Banking Sector of Ghana. International Journal of Business and Management 11(1): 249262. https://doi.org/10.5539/ijbm.v11n1p249.

Magatef SG, Tomalieh EF. 2015. The impact of customer loyalty programs on customer retention. International Journal of Business and Social Science 6(8):78-93

Minh NV, Huu NH. 2016. The relationship between service quality, customer satisfaction and customer loyalty: An investigation in Vietnamese retail banking sector. Journal of Competitiveness 8(2):103-116.https://doi.org/10.7441/ joc.2016.02.08.

Ou WM, Shih CM, Chen CY, Wang KC. 2011. Relationships among customer loyalty programs, service quality, relationship quality and loyalty: An empirical study. Chinese Management Studies 5(2):194-206. https://doi. org/10.1108/17506141111142825.

O'Sullivan D, McCallig J. 2012. Customer satisfaction, earnings and firm value. European Journal of Marketing 46(6):827-843. https://doi. org/10.1108/03090561211214627.

Rai AK, Srivastava M. 2012. Customer loyalty attributes: A perspective. NMIMS Management Review 49-76.

Rastogi V, Utama E, Choudhury S. 2016. Understanding the shopping habits of Indonesia's middle class.http://www.thejakartapost.com/ news/2016/02/18/understanding-shoppinghabits-indonesia-s-middle-class.html [March 26, 2017]

Schepers J, Nijssen, EJ. 2018. Brand advocacy in the frontline: how does It affect customer satisfaction. Journal of Service Management 29(2): 230-252. https://doi.org/10.1108/JOSM-07-2017-0165.

Schmitt P, Skiera B, Bulte CV. 2011. Why customer referrals can drive stunning profits. UK: Harvard Business Review.
Shailesh G, Reddy, DB. 2016. Mediation role of customer advocacy in customer loyalty and brand equity relationship - An empirical study in context to in-store brands. Indian Journal of Science and Technology 9(45): 1-8. https://doi. org/10.17485/ijst/2016/v9i45/104492.

Suryadi D. 2015. Merek-merek unggulan asli Indonesia. SWA Magazine 45.

Susanta, Alhabsji T, Idrus M, Nimran U. 2013. The effect of relationship quality on customer advocacy: The mediating role of loyalty. IOSR Journal of Business and Management 10(4): 4152. https://doi.org/10.9790/487X-1044152.

TaghiPourian, MJ, Bakhsh, MM. (2015). Loyalty: From single-stage loyalty to four-stage loyalty. International Journal of New Technology and Research 1(6): 48-51.

Tarigan J, Hatane, SE. 2019. The Influence of Customer Satisfaction on Financial Performance Through Customer Loyalty and Customer Advocacy: A Case Study of Indonesia's Local Brand, International Conference on Economics, Education, Business and Accounting; Bali, 25-27 October 2018:270-284. https://doi.org/10.18502/ kss.v3i11.4012.

Tarigan J, Hatane SE, Stacia L, Widjaja DC. 2019. Corporate social responsibility policies and value creation: does corporate governance and profitability mediate that relationship? Investment Management and Financial Innovations 16(2): 270-280. https://doi.org/10.21511/ imfi.16(2).2019.23.

Tarigan J, Listijabudhi S, Hatane SE, Widjaja DC. 2019. The impacts of intellectual capital on financial performance: an evidence from Indonesia Manufacturing Industry. Indonesian Journal of Business and Entreprenuership 5(1): 65-76. https://doi.org/10.17358/ijbe.5.1.65.

Williams P, Naumann E. 2011. Customer satisfaction and business performance: a firm-level analysis. Journal of Services Marketing 25(1): 20-32. https://doi.org/10.1108/08876041111107032. 